\title{
Violence against Women Digitized: An Analysis of Times of India Online Videos after the Delhi Gang Rape
}

\author{
Amani Ismail, The American University in Cairo, Egypt \\ Smeeta Mishra, Institute of Management Technology, India
}

\begin{abstract}
This study examined Times of India's online portrayal of violence against women during the summer of 2013, about six months after the Delhi Gang Rape. We used a purposive sample of news videos reporting violence against women that were published on the Times of India website. We performed textual analysis to answer two research questions. First, how was violence against women portrayed in TOI's online video footage? And second, how do such portrayals contribute to our understanding of the role of new media in communicating social conflict to their audiences? That the videos contain both visual and auditory components was conducive to the study's purpose due to the graphic nature of violence, and thus news decisions regarding imagery and sound become crucial to understanding how media construct these events. Results show that in cases of violent crime against women, the survivor was violated twice: by both the perpetrator and the media as she is neither treated with dignity nor is her privacy respected.
\end{abstract}

Keywords: Women, Violence, Online News, Media, India, Visual 
An international poll of gender specialists ranked India fourth among the world's most dangerous countries for women in 2011 (Clingmon, 2011). The Thomson Reuters Foundation report claimed that high rates of female feticide, infanticide and human trafficking have put the country, an emerging economic powerhouse, high on that list (Express News Service, 2011). While this report alarmed many, it did not bring discussions on violence against women in India to the forefront. What brought unprecedented focus on the issue was the media coverage of the Delhi Gang Rape case and the subsequent death of the 23-year-old medical student in December 2012. Protests against the police and the government erupted in New Delhi and many other Indian cities following the incident. Collective outrage against the incident led the Indian government to revise laws pertaining to sexual violence (Hundal, 2013).

Against the backdrop of India's media image as a female-unfriendly place, this study examines violence against women as portrayed in the online video footage of the Times of India (the largest selling English-language newspaper in the country) in the summer of 2013 - five months after the Delhi Gang Rape case. It also seeks to unravel how such portrayals contribute to our understanding of the role of new media in communicating social conflict to their audiences.

\section{Literature Review}

The media arguably play a vivid role in "creating a common sense of the world through its particular language and symbolization” (Alat, 2006, p. 296). A more condemning school of thought argues that media representations "create an impression of events rather than an accurate, factual record of what took place" (Berrington \& Honkatukia, 2002, p. 50). If for that type of reasoning alone, interrogating how media tackle a subject matter as sensitive and consequential as violence, particularly physical/sexual assault, becomes a pressing scholarly endeavor.

Trends in mass media coverage of violence against women generally indicate that media work to reify long-standing, misogynistic outlooks on women. A study of U.S. popular magazines concludes that the character of their narratives "contributes to a set of cultural and social expectations that ultimately allows men to strike women" (Nettleton, 2011, p. 154).Indeed, media help construct hegemonic masculinity (Lapsansky \& Chatterjee, 2013). 
One of the most prominent examples of violence against women in many so-called traditional societies is honor killing, which is "originally the product of a particular social interaction amongst members of the society which believes in a strong patriarchal structure" (Malik, 2013, p. 1). Adultery, premarital relationships, or assertion of right to marry according to their choice are widely known causes for honor killings (Malik, 2013).

In an audience study, Kahlor and Eastin (2011) found that general television consumption is related significantly to first- and second-order rape myth beliefs among adult men and women beyond the college student population. The first order refers to beliefs about the prevalence of rape while the second order refers to related beliefs about society. Rape myths refer to false but persistent beliefs and stereotypes regarding forced sexual intercourse and the victims and perpetrators of such acts (Lonsway \& Fitzgerald, 1994 in Kahlor \& Eastin, 2011), such as fabricating rape claims or that women claiming rape are promiscuous.

Sexist news coverage of violent crimes against women is elucidated in context of cultural norms that accord women in a given society less-than-equal rights as men. In Turkey, for instance, premarital and extramarital sexual contact is forbidden for women but not for men (Alat, 2006). In a study of how online versions of four Turkish liberal newspapers covered crimes against women, Alat (2006) detected a "victim blaming attitude" (p. 301), whether in the headlines or text of news stories; even victims" "adherence to norms, their lifestyles and their provocative or careless behavior are put under scrutiny" (p. 301).

On a note more directly related to our study, Daniel Drache and Jennifer Velagic (2013) examined press coverage over the three-month period after the Delhi Gang Rape in four leading Indian English-language publications and found that "rape reporting increased by roughly $30 \%$ after the Delhi rape, with the Delhi Rape taking between 10-20\% of the share of rape stories across varying storylines." The four publications including The Hindu, India Today, the Indian Express, and Tehelka have a combined circulation of 2,946,340. Drache and Velagic also identified five dominant storylines in the rape coverage: personal storyline, public outcry, women's safety, police handling, and legislative.

"The structure of patriarchal power has worked against the interests of women in the way sexual crimes are reported in India and other societies" (Drache \& Velagic, 2013). It is this 
deep-seated patriarchy that explains why honor killings still take place in India today despite being "grossly" against the Indian constitutional right to equality before the law or the equal protection of the laws; these killings are mainly directed towards women and thus give rise to gender inequality (Malik, 2013, p. 2).

Drache and Velagic's (2013) study shows that the Indian press often engages in incidentbased reporting of sexual crimes and does not examine the causes and prevention of such violence from a gender justice perspective. They conclude that the "Indian press needs to take a hard look at its coverage of sexual violence if it intends to have a higher standard of journalism with a modern view of sexual crimes and violence."

Drache and Velagic (2013) found that the Indian print media usually highlight "the individual story of one survivor, one event, or one episode of violence" without providing context and analysis. A story that gets top coverage one day may disappear completely in little time unless civil society groups protest or keep the issue alive.

The press needs to move beyond merely reporting the incident and its sensational aspects to an in-depth analysis of the structures of patriarchal power. Drache and Velagic (2013) argue that the culture of the Indian newsroom also needs to change: "The responsibility for a different kind of news culture relies on both the editorial direction of the newspapers we examined, and also the reporters, who are the frontline professionals."

Khan (2010) argues that Indian media compromise quality for quantity in their coverage of sex crimes: "Often stories on violent crimes are poorly researched, insensitively reported, intrusive, more sensational than accurate, sexist, class-biased and occasionally even personally motivated" (p. 86).

Interestingly, similar coverage features have been noted in Western news media. A comparative news coverage study involving a British woman violence victim and a Finnish woman violence victim drew an important parallel between the two non-identical cases: "The underlying message is clear: young women should remain within patriarchal and familial control to minimize their chance of victimization" (Berrington \& Honkatukia, 2002, p. 69). 
Research on North American newspaper coverage of battered women who killed their abusive partners found that the predominant social construction of those women was "one of female deviants; they were either mad or bad" (Noh, Lee \& Feltey, 2010, p. 126). The authors suggest that the sensationalist portrayals they detected arise from media's desire to generate public interest, as they are concerned with "generating new angles on old stories" (p. 126).

In a similar vein, an article critiquing Canadian media coverage of a series of missing and murdered Canadian women, pointedly observes: "The media gaze became focused on sexual deviance and what happened to the young women, a curiosity fanned by a voyeuristic and morbid fascination with the visual recordings on the [television] tapes" (Jiwani \& Young, 2006, p. 911).

In the new media realm, evidence suggests that anti-feminist depictions are alive and well. A 2013 study of YouTube videos found that nearly one-fourth of the sampled videos had representations of misogynistic discourse, violence, or both. The following summarizes what this portion of the videos was like:

These videos all had one thing in common: the primary actor or actors were male. Statements in some of the videos were so offensive as to afford the label of obscene. Three of the videos referred to the molestation of a female child, while others used offensive language referring to female genitalia, referring to women and girls as bitches, and sexualizing and objectifying women and girls. (Tucker-McLaughlin, 2013, p. 45)

\section{Methods}

We analyzed a purposive sample of 53 videos dealing with violence against women posted on the Times of India website between May 1 and June 15, 2013. These videos belong to Times Now, a 24-hour English news language channel owned by The Times Group (Bennett, Coleman \& Co. Ltd). The Times Now channel is based in Mumbai and broadcast in India, Singapore and the United States. For this study's purposes, we will be referencing the examined material as TOI videos as they were posted on the Times of India website. We stopped sample collection when we had a substantial number of videos and the patterns were being repeated. We decided to focus on the topic of "violence against women" rather than "crime against women" in order to get a larger pool of videos that highlight how various forms of violence against women are represented in online videos. We used the method of 
textual analysis to examine the video coverage on violence against women. According to Alan McKee (2003), textual analysis is "a methodology for gathering information about sense-making practices, that is, how members of various cultures interpret the world around them," (p. 63).

We base our choice of online video coverage (as opposed to print coverage) partly on this contention: "Although visual framing of an event in the news media is a crucial area of inquiry, unfortunately much of the communication scholarship has not focused on images and only attracted the attention of a few media scholars" (Neumann \& Fahmy, 2012, p. 173). Further, past research has detected a relationship between a given news medium's ideology and the visual framing the medium engages in (Fahmy, 2007).

Referring to analysis of moving images, Diana Rose (2000) points out that since "audiovisual media are a complex amalgam of meanings, images, techniques, shot framing, shot sequence and much more," it is important that researchers take the complexity of the material into account while examining them (p. 246). While we have attempted such an exercise in our analysis of news video footage on violence against women published on the Times of India website, we also concede with Rose (2000) that some information may be lost and some other added in this analytical process which involves translation and interpretation of audiovisual material (p. 247).

While examining the videos, we picked the "most interesting and relevant parts" of the coverage for analysis (McKee, 2003, p. 80). Since context is critical to the interpretive process, we constantly took into account the socio-cultural milieu in which these videos were produced. We identified instances of "exnomination" with the purpose of unraveling what was presented as "common sense" and "normal" in these texts (McKee, 2003). We also analyzed both inclusions and exclusions in the news video coverage on violence against women. Given the above, we attempt to answer the follow research questions in our study: RQ1: How was violence against women portrayed in TOI's online video footage?

RQ2: How do such portrayals contribute to our understanding of the role of new media in communicating social conflict to their audiences? 


\section{Results: Analysis of News Clips}

Our paper poses two research questions. On the base level, it interrogates how violence against women was portrayed in TOI's online video footage. On the next level, it asks how such portrayals contribute to our understanding of the role of new media in communicating social conflict to their audiences. We first tackle our foundational question.

\section{Double Violation and Vivid Attention to Private Detail}

Sensationalism largely defined TOI's coverage of violence against women during the examined time period. Whether it was rape, beating, or abuse of women in general, coverage tended to adopt a hyped approach tinted with what seemed to be an editorial rather than a straight news orientation. Examples abound in our selected sample of online video clips.

In cases of violent crime against women, the individual is violated twice: first by the perpetrator and then by the media. As an analysis of the clips in our sample show, she is neither treated with dignity nor is her privacy respected. For instance, in a story titled “Another shame: 30-year-old gang-raped in UP" dated June 12, 2013, the voiceover informed the viewers that a women was battling for her life after she was brutally gang raped and shot at. The blurred visuals in the video showed a woman drenched in blood from the waist down lying on a hospital bed. The voiceover reiterated that the woman was lying in a pool of blood and trying to forget the horrible things that happened the night before (Another shame, 2013).

Meanwhile, the visuals showed a male reporter approaching the woman's hospital bed and asking her: "Did they rape you?" The camera showed a blurred close-up shot of the woman. When the woman said yes, the reporter asked: "How many men were there?" The woman answered that there were 5 men, a piece of information that had already been given to the viewer at the start of the story. The shot ended with loud background music and a voiceover providing the details of the incident: The woman was returning home with her nephew when the "brutes dragged her into the bushes and raped her." The rape survivor's nephew tried to oppose them and he was attacked too. A police official was then interviewed with visuals of the woman wrapped in a blood-soaked sheet dominating the other half of the screen. Finally, the story closed with visuals of protests during the Delhi gang rape case and the voiceover announcing that the politicians are getting way with just doing the basic minimum (Another shame, 2013). 
While the reporter established a pattern in violent crimes against women by linking the incident with the Delhi gang rape, the story, merely reported the incident. And, in order to do so, the reporter violated the dignity and privacy of the rape survivor several times. The reporter, who behaved more like a police investigator, dehumanized the incident by the nature of his questions apart from the location and timing of the interview. The rape survivor was made to narrate her experience all over again in front of the camera and in the presence of several people. Here, it may be added that India has a two-tier health service system. While the rich go to private hospitals which offer excellent facilities for a heavy price, the poor go to government-run hospitals which often run on scarce supplies. What is evident from many stories on sex crimes is that the medical personnel in these government-run hospitals often allow the reporter to reach the bed of the injured woman even when her health is in a critical condition. It is very unlikely that a private hospital catering to the upper classes would allow such a breach of privacy.

Furthermore, such stories on rape and mutilation of women often carry visuals and interviews of the individual's grief-stricken mother and other loved ones. In an article aptly titled "When Sympathy Turns to Voyeurism," Mia Freedman (2011) asks why we have a need to see people in grief when they are crying and losing their composure. More specifically, she asks: "Why the desire to package grief as pseudo-entertainment with music and slo-mo? There's little dignity in that." Labelling such coverage as "grief pornography," Freedman writes:

In every tragedy, there's a subtle shift that happens in the media coverage. Or maybe the shift is in our perception of it. Either way, at a certain point, coverage slips from news gathering to voyeurism. At its worst it can deteriorate into grief porn, an ugly side of journalism and human nature alike. It may be a natural instinct to rubberneck when you drive past an accident, but it's another thing altogether to pull over, get out of your car, have a good stare, wait until the victim's relatives arrive and peer intently as their faces contort with distress. That's grief porn.

In our sample, such visuals and bytes detailing the pain and horror of survivors abound. In another story titled "Lover's father sets girl on fire in Uttar Pradesh" dated June 14, 2013, the camera takes the viewer to the hospital bed where the girl, who was set on fire by her lover's father, was lying injured. Although the picture was blurred, one could still see much of the girl and her surroundings. The incident took place in Deoria, a small town located in the north Indian state of Uttar Pradesh. The male reporter interviewed the girl although she could barely speak due to her burn injuries (Lover's father, 2013). Then, the reporter interviewed 
the girl's mother and informed the viewer that the girl was battling for her life. The story ended with a byte from a police officer. Apart from reporting the incident and focusing on the individual story, the reporter offered no context in terms of the township of Deoria, its demographics or any analysis of the nature of the crime, its cause and likely prevention.

Worse still, the Indian media display a high degree of intrusiveness and insensitivity even in their coverage of crimes against minors. A story titled "Arrested for rape, Meghalaya cop escapes from custody" began with visuals of two minor girls sitting outside their home in Meghalaya, a state in North-eastern India. Only the faces of the two rape survivors were blurred and their eyes covered with a dark patch in the visuals. As one watched the two young girls on screen, the voiceover informed: "These sisters have been scarred for life. Tormented by a man who was meant to protect them" (Arrested for, 2013). The girls were reportedly raped and molested by a policeman first inside a police station and then at their home while being held at gunpoint. The reporter interviewed one of the girls and asked her to describe her ordeal in the police station. Then the second girl was interviewed about the rape at home. Although the girls were under 18 years of age, the reporter did not hesitate to give them the same treatment - Violate their privacy and ask them to describe their ordeal in front of the camera.

Perhaps the only women the Indian media find it difficult to subject to such treatment are Western tourists visiting India. For instance, in a story titled "American tourist gang-raped in Manali: Police" the visuals did not show the rape survivor. Instead, the visuals were that of the guest house where she stayed in Manali, a tourist destination 500 kilometers from New Delhi. The reporters did not interview the survivor. Only a senior police official was interviewed. The reporter informed the viewer that the truck driver who gave the survivor a lift reportedly raped her along with two of his accomplices (American tourist, 2013). The police officer then assured viewers that all three men were in their custody and steps were being taken to prevent such mishaps from happening.

\section{Editorialized Coverage Complements Sensational Package}

Language-wise, editorializing news coverage came through crystal clear. An illustrative instance is a May 14 video telling the story of a 14-year-old girl who reportedly attempted suicide after being subjected to a rape attempt by a young male (Shocking: Teenager 
allegedly, 2013). After launching the clip with footage of her lying down, though her eyes are concealed by a black strip for privacy reasons, the reporter's voiceover tells us, "She has endured what few her age can even comprehend." The reporter's bias emerges as she declares that "the man accused of the heinous crime easily claims innocence." Sound effects were also utilized as part of the sensational package offered to video viewers. Dramatic music is hard to miss as news of India-based violence aired on those e-videos (e.g. Aarushi case make, 2013; Class XII girl, 2013).

The producers' own editorial touch on the aired footage also stands testament to the sensational package. A consistent feature of the news reports was the use of red circles surrounding either accused individuals or victims in given violence cases or even red arrows pointing to suspects and/or victims. Among others, one example is a May 10 video reporting on former Haryana Minister Gopal Goyal Kanda and his aide Aruna Chadha being charged in the Geetika Sharma suicide case (Geetika case, 2013). Footage from August of 2012 displays both men surrounded by a red circle and that image is juxtaposed against a picture of the victim, one where she appears as young, attractive, and dressed in the traditional sari. A May 14 video (Shocking: Policemen strip, 2013) reports on police officers at a railway station who strip-searched a woman they suspected might have stolen golden pendants from fellow train passengers; red circles and red arrows were used to zero in on the woman in the clip.

Interestingly, international stories in the given sample emanated only from the United States with a few exceptions - namely, the story of Ariel Castro who was charged for four counts of kidnapping and three counts of rape (Kidnap, rape charges, 2013; Castro had violent, 2013); the "growing epidemic" of sexual harassment against women within the U.S. military (U.S. military sex, 2013); a 12-year-old boy's stabbing of his own 8-year-old sister in California (Stepbrother arrested in, 2013); as well as the story of an "outspoken nationalist [Japanese] mayor" who said that "the forced prostitution of Asian women before and during WWII was necessary to maintain the discipline in the ranks and provide rest for soldiers who risked their lives in battle" (Protests arise over, 2013).

Whether within Indian or international news reports, the pronounced level of controversy characterized the coverage, but particularly so in the Indian realm. Reporters' voiceovers did not shy away from blatantly editorialized statements even regarding cases that were still 
under way and far from over. Examples include but are not limited to, a May 14 story on the slapping of an Indian girl inside a police station where the cops assaulted here because they were "questioning her character" (Caught on cam, 2013). The reporter launches the report as follows: "In yet another incident of brazen abuse of power..." Another illustration is the rape of a 14-year-old who was set ablaze by the rapists, as we hear the reporter say, "This 14-yearold has displayed unwavering resolve to live and bring her perpetrators to justice" (MP teen raped, 2013). As for the story of a woman who was strip-searched on suspicion of theft, the video headline read "Who will police the police?" and the woman involved was referred to as "the victim" (Shocking: Policemen strip, 2013).

The aforementioned U.S. and Japanese military stories as well as the policemen's beating of a young woman at the station were certainly not the only instances where sexual misconduct on the part of men towards women as part of power abuse was highlighted. A May 14 story reports on the wife of a senior Indian Navy officer who charged her husband with forcing her to get "'sexually involved" with his colleagues, prompting the defense minister to order a probe so as to legally investigate those grave charges (Indian Navy hit, 2013).

We now turn to the question of how the above-explicated coverage patterns inform our understanding of how new media communicate social conflict to their audiences.

\section{Urban, Middle/Upper-Class Media Bias}

In large measure, the videos under study confirm that the long-practiced sensational coverage of conflict news (no less when it involves a threat to social order and stability as with charges of violating women's safety and dignity and abusing the public trust supposedly bestowed upon officials by the people) is alive and well. Furthermore, however, the Indian media's class bias is visible in the saturation coverage of cases from the middle and upper classes in urban India. The case that received maximum publicity during the period analysed for this study was the Aarushi-Hemraj Murder Case (also called the Noida Double Murder case). First, we offer a background of the Aarushi-Hemraj Murder case. On May 16, 2008, 14-yearold Aarushi Talwar and Hemraj, a domestic help employed by her family, were found murdered at her home in Noida, an affluent suburb of Delhi located in the neighbouring state of Uttar Pradesh. Aarushi's parents are dentists. While the case remained unsolved during the time period analyzed in this study, it received immense media coverage throughout. The 
Central Bureau of Investigation charged Arushi's father, Dr. Rajesh Talwar, for allegedly killing her and their domestic help with a golf stick and a sharp-edged weapon after finding them in an "objectionable position" (Press Trust of India, 2013). In November 2013, the dentist couple were sentenced to life imprisonment on charges of murder and destruction of evidence. A media report on the verdict stated: "The conviction of the Talwar couple in the Aarushi-Hemraj murder case on Monday brought closure to a trial that had the nation transfixed" (Talwar couple, 2013).

Commenting on the nature of media coverage of the case, Shoma Chaudhury, then managing editor of a weekly newsmagazine and popular web portal, Tehelka.com, wrote: "Over the last five years, the media has mashed and cooked and masticated this story in any way they choose." Chaudhury (2013) further elaborated:

Screaming headlines, television reconstructions of dark silhouettes, a 13-year-old girl having sex with a naked man, a father with a raised golf club, hysterical background music, incessant police and CBI [Central Bureau of Investigation] theories put out in the public domain. All of this has done the trick. This is now a closed case: the Talwars have already been convicted in the public mind society's desire for vicarious spectacle.

Madhur Singh (2008) compared the coverage of this case with that of the JonBenet Ramsey case in the United States in a report published in the Time magazine. Singh argues that the Aarushi-Hemraaj murder case reveals "deeper flaws in Indian policing and the country's media. Critics have renewed calls for the press to conform to proposed legislation that would regulate journalistic standards, a bill the media has fought."

Indian media have supported survivors of sexual violence by providing continual coverage and keeping the issues alive in the minds of the public and members of civil society groups. But such cases where the media have played a crusading role are limited to cases from the middle and upper classes in urban areas. For example, cases where media have zealously taken up the cause of the survivors and/or their family members include the Delhi Gang Rape case, the Priyadarshini Mattoo case, the Jessica Lal murder case, and the Ruchika Girhotra case, among others. Apart from the gruesome nature of the crime, one of the reasons the Delhi Gang Rape received so much media and public attention was the fact that "the rape victim represented the upwardly mobile lower-middle class that has benefited from India's 
economic growth, while the male perpetrators stand in the shadows with those left out of the Indian growth engine" (Examining violence, 2013, p. 3). Thus, Khan (2010) emphasizes that crimes that "violate the body of the middle-class woman" get a lot of media attention (p. 84). Referring to a brutal gang rape of a 20-year-old in a small village in West Bengal on June 7, 2013, feminist scholar, Soma Marik, argues:

Not all rapes are treated in the same way. The rape of a woman in Delhi stirs us more, the rape of a woman in Barasat less. The Delhi rape did not only lead to huge protests in Delhi. They even led to huge protests and discussions in Kolkata and elsewhere in India. The rape and murder of a young woman in a mofussil town is not so exciting and not so easily deserving of mass spontaneous expression of anger (Nigam, 2013).

It is possible that the Indian media, especially English-language media, display an urbanmiddle-class bias because its viewers and readers primarily belong to these classes and advertisers are keen to reach out to them (Khan, 2010). Furthermore, since most journalists working for English-language media belong to the middle and upper classes, they may be particularly drawn to issues affecting their own class.

Highlighting only those cases that involve middle class women and/or specific types of sexual violence can have serious implications. For instance, Zain Lakhani cautions that the local and international attention on the Delhi Gang Rape case has "placed in the public eye a set of assumptions about what rape looks like" (Examining violence, 2013, p. 3). Lakhani explains that since most acts of violation against women "do not occur in public and/or gang rape scenarios," having a restrictive understanding of sexual violence that primarily draws upon sensational cases such as the Delhi Gang Rape case, may lead to marginalization of women whose experiences do not fit such definitions or scenarios. Thus, the media need to highlight not just the sensational cases that remain in the public eye for long periods of time but the ones that get lost in the humdrum of everyday news production.

\section{Conclusion}

Our textual analysis indicated two patterns occurring in tandem yet are divergent in their nature and impact: empathy with the violated female sexual victim alongside intrusive treatment of sexual violence crimes and a classist bias in coverage. The former alone would seem to be relatively benign - provided it does not come at the expense of objective, fair and 
balanced portrayals of both alleged perpetrator and victim. The latter, on the other hand, bodes ill for the ideal goal of even-handed journalism that is neither sensational nor skewed in favour of certain citizens over others. Perhaps the most advantageous outcome of targeting visual news clips is that, as expected, it underscored aspects of coverage that would not be at the journalist's disposal in a print news context. That the victim ends up being doubly violated represents a cause for concern. After all, news media should serve as watchdogs over wrongdoing in society rather than aides in worsening societal ailments.

Of course, we are conscious that among the study's limitations is the time period analyzed, as it came on the heels of a critical event in the media and public spheres alike - the Delhi Gang Rape. We, therefore, recommend that future studies within this domain select time periods that are relatively distant from such landmark events in order to help mitigate their potential effect on coverage of other sexual violence cases. We also recommend that future research supplement textual/content analysis with in-depth interviewing of reporters who cover stories in this genre. This could well shed light on factors that play a role in constructing such events for audiences, factors that journalists find themselves inevitably grappling with when assigned those stories. 


\section{References}

Aarushi case make ex-CBI director a witness, say parents. (2013, May 1). Times Now.

Retrieved May 21, 2013 from Times of India Website:

http://timesofindia.indiatimes.com/videos/news/Aarushi-case-Make-ex-CBI-director-awitness-say-parents/videoshow/19816502.cms

Alat, Z. (2006). News coverage of violence against women: The Turkish case. Feminist Media Studies, 6(3), 295-314.

American tourist gang-raped in Manali: Police. (2013, June 4). Times Now. Retrieved May 19, 2014, from Times of India website:

http://timesofindia.indiatimes.com/videos/news/American-tourist-gang-raped-inManali-Police/videoshow/20430665.cms

Another shame: 30-year-old gang-raped in UP (2013, June 12). Times Now. Retrieved May 10, 2014, from Times of India Website:

http://timesofindia.indiatimes.com/videos/news/Another-shame-30-year-old-gangraped-in-UP/videoshow/20550530.cms

Arrested for rape, Meghalaya cop escapes from custody. (June 5, 2013). Times Now.

Retrieved May 11, 2014, from Times of India website:

http://timesofindia.indiatimes.com/videos/news/Arrested-for-rape-Meghalaya-copescapes-from-custody/videoshow/20445243.cms

Berrington, E., \& Honkatukia, P. (2002). An evil monster and a poor thing: Female violence in the media. Journal of Scandinavian Studies in Criminology and Crime Prevention, 3, $50-72$.

Castro had violent past: Ex-daughter-in-law. (2013, May 10). Times Now. Retrieved May, 22, 2013, from Times of India Website:

http://timesofindia.indiatimes.com/videos/news/Castro-had-violent-past-Ex-daughterin-law/videoshow/19982215.cms

Caught on cam: UP cop slaps girl inside police station. (2013, May 14). Times Now.

Retrieved May 22, 2013, from Times of India Website:

http://timesofindia.indiatimes.com/videos/news/Caught-on-cam-UP-cop-slaps-girlinside-police-station/videoshow/20041651.cms

Chaudhury, S. (2013, June 29). Framed? The Aarushi-Hemraj murder case - An investigation. Tehelka, 26 (10). Retrieved July 1, 2013, from http://www.tehelka.com/framed-the-aarushi-hemraj-murder-case-an-investigation/ 
Class XII girl student shot dead in Delhi's Munirka area. (2013, May 10). Times Now. Retrieved May 22, 2013, from Times of India Website: http://timesofindia.indiatimes.com/videos/news/Class-XII-girl-student-shot-dead-inDelhis-Munirka-area/videoshow/19984628.cms

Clingmon, S. (2011). Poll: The 5 most dangerous countries for women. PBS.org. Retrieved April 10, 2014, from: http://www.pbs.org/newshour/rundown/poll-five-mostdangerous-countries-for-women/

Drache, D. \& Velagic, J. (2013). A report on sexual violence journalism in four leading Indian English language publications before and after the Delhi Rape. Retrieved May 18, 2014, from http://papers.ssrn.com/sol3/papers.cfm?abstract_id=2277310

Express News Service (June 15, 2011). India fourth most dangerous country for women: Poll. The Indian Express, Retrieved May 10, 2014, from: http://archive.indianexpress.com/news/india-fourth-most-dangerous-country-forwomen-poll/803716/

Examining violence against women in India: Changes, challenges, and futures (2013, May) Asia Report (20), Sigur Center for Asian Studies, George Washington University. Retrieved May 5, 2014, from: https://www.gwu.edu/ sigur/assets/docs/publications/asiareports/asiareport20.pdf Fahmy, S. (2007). "They took it down": Exploring determinants of visual reporting in the toppling of the Saddam statue in national and international newspapers. Mass Communication and Society, 10(2), 143-170.

Freedman, M. (2011, September 12). When sympathy turns to voyeurism. The Sydney Morning Herald. Retrieved May 5, 2014, from: http://www.smh.com.au/federalpolitics/society-and-culture/when-sympathy-turns-to-voyeurism-20110912-1k4n7.html

Geetika case: Court orders framing of charges against Gopal Kanda. (2013, May 10). Times Now. Retrieved May 22, 2013, from Times of India Website: http://timesofindia.indiatimes.com/videos/news/Geetika-case-Court-orders-framing-ofcharges-against-Gopal-Kanda/videoshow/19987816.cms

Hundal, S. (2013, December 10). Delhi rape: one year on, has anything changed for India's women? The Guardian. Retrieved April 12, 2014, from http://www.theguardian.com/world/2013/dec/10/delhi-rape-one-year-anythingchanged-india-women 
Indian Navy hit by another sex scandal; Antony orders probe. (2013, May 14). Times Now. Retrieved May 24, 2013, from Times of India Website:

http://timesofindia.indiatimes.com/videos/news/Indian-Navy-hit-by-another-sexscandal-Antony-orders-probe/videoshow/20051559.cms

Jiwani, Y., \& Young, M.L. (2006). Missing and murdered women: Reproducing marginality in news discourse. Canadian Journal of Communication, 31, 895-917.

Kahlor, L., \& Eastin, M. (2011). Television's role in the culture of violence toward women: A study of television viewing and the cultivation of rape myth acceptance in the United States. Journal of Broadcasting \& Electronic Media, 55(2), 215-231.

Khan, S. (2010) When survivors become victims. In Sharma, K. (Ed.) Missing, half the story: Journalism as if Gender Matters (pp. 83-118). New Delhi: Zubaan.

Kidnap, rape charges for Ohio man; women go home. (2013, May 9). Times Now. Retrieved May 21, 2013, from Times of India Website: http://timesofindia.indiatimes.com/videos/news/Kidnap-rape-charges-for-Ohio-manwomen-go-home/videoshow/19963918.cms

Lapsansky, C., \& Chatterjee, J. (2013). Masculinity matters: Using entertainment education to engage men in ending violence against women in India. Critical Arts, 27(1), 36-55.

Lover's father sets girl on fire in Uttar Pradesh (2013, June 14). Times Now. Retrieved May 12, 2014, from Times of India website: http://timesofindia.indiatimes.com/videos/news/Lovers-father-sets-girl-on-fire-in-UttarPradesh/videoshow/20584137.cms

Malik, P. (2013). Honour-based violence with special reference to "Khap Panchayat" in Haryana and the Indian panel code. Indian Streams Research Journal, 3(5) [Online: www.isrj.net].

McKee, A. (2003). Textual analysis: A beginner's guide. London: Sage Publications. MP teen raped, set ablaze; now justice denied. (2013, May 14). Times Now. Retrieved May 22, 2013, from Times of India Website: http://timesofindia.indiatimes.com/videos/news/MP-Teen-raped-set-ablaze-nowjustice-denied/videoshow/20041743.cms

Nettleton, P. (2011). Domestic violence in men's and women's magazines: Women are guilty of choosing the wrong men, men are not guilty of hitting women. Women's Studies in Communication, 34, 139-160. 
Neumann, R., \& Fahmy, S. (2012). Analyzing the spell of war: A war/peace framing analysis of the 2009 visual coverage of the Sri Lankan Civil War in Western newswires. Mass Communication and Society, 15,169-200.

Nigam, A. (2013, June 17). Barasat rape, murder and the culture of rape in West Bengal: Soma Marik. Kafila. Retrieved from: http://kafila.org/2013/06/17/barasat-rape-murderand-the-culture-of-rape-in-west-bengal-soma-marik/

Noh, M., Lee, M., \& Feltey, K. (2010). Mad, bad, or reasonable? Newspaper portrayals of the battered woman who kills. Gender Issues, 27, 110-130.

Press Trust of India (2013). Aarushi-Hemraj murder case: CBI says Rajesh Talwar found the two in objectionable position. India Today. Retrieved May 6, 2014, from: http://indiatoday.intoday.in/story/aarushi-hemraj-murder-cbi-rajesh-talwarobjectionable-position/1/267287.html

Protests arise over Osaka mayor's remarks on comfort women. (2013, May 15). Times Now. Retrieved May 24, 2013, from Times of India Website: http://timesofindia.indiatimes.com/videos/news/Protests-arise-over-Osaka-mayorsremarks-on-comfort-women/videoshow/20068011.cms

Rose, D. (2000). Analysis of moving images. In Bauer, M.W., \& Gaskell, G. (Eds). Qualitative Researching with text, image and sound: A practical handbook (pp. 246262). London: Sage.

Shocking: Policemen strip woman on suspicion. (2013, May 14). Times Now. Retrieved May 23, 2013, from Times of India Website: http://timesofindia.indiatimes.com/videos/news/Shocking-Policemen-strip-woman-onsuspicion/videoshow/20050827.cms

Shocking: Teenager allegedly raped and burnt alive. (2013, May 13). Times Now. Retrieved May 22, 2013, from Times of India Website: http://timesofindia.indiatimes.com/videos/news/Shocking-Teenager-allegedly-rapedburnt-alive/videoshow/20024084.cms

Singh, M. (2008, May 29). India's JonBenet Ramsey case? Time.com, Retrieved May 8, 2014, from: http://www.time.com/time/world/article/0,8599,1810162,00.html

Stepbrother arrested in California stabbing; community saddened. (2013, May 14). Times Now. Retrieved May 23, 2013, from Times of India Website: http://timesofindia.indiatimes.com/videos/news/Step-brother-arrested-in-Californiastabbing-community-saddened/videoshow/20043434.cms 
Talwar couple get life sentence in Aarushi-Hemraj double murder case (2013, November 16). India Today Online. Retrieved May 10, 2014, from:

http://indiatoday.intoday.in/story/aarushi-hemraj-murder-verdict-talwars-ghaziabadcourt/1/326596.html

Tucker-McLaughlin, M. (2013). YouTube's most-viewed videos: Where the girls aren't. Women and Language, 36(1), 43-49.

U.S. military sex assault reports up; changes ordered. (2013, May 9). Times Now. Retrieved May 21, 2013, from Times of India Website:

http://timesofindia.indiatimes.com/videos/news/US-Military-sex-assault-reports-upchanges-ordered/videoshow/19963946.cms 